\title{
A SWOT Analysis of General Aviation Industry Development in Shandong Province
}

\author{
Shouxi Zhu \\ Flying College \\ Binzhou University \\ Binzhou, China \\ zhushouxi@163.com
}

\author{
Xinjun Gong \\ Cabin Attendants College \\ Binzhou University \\ Binzhou, China \\ bzxygxj@126.com
}

\begin{abstract}
General aviation is an important part of civil aviation. General aviation has a large industrial group and long industrial chain, which can greatly promote regional economic development. In this paper, we study the external factors of general aviation industry development in Shandong Province such as politics, economy, society, science and technology using SWOT analysis. Analyze the strengths of location, economy, policy, weather etc., the weakness of lack of talents, lack of airports and relevant facilities etc., the opportunities such as government support and the wide prospect of market etc., and the threat factors such as fierce market competition, volatile market and so on. Based on this, presents the four strategies of positive development, reducing weakness, avoiding threats and defense. These strategies can provide certain help for formulating relevant policy of the general aviation industry in Shandong Province.
\end{abstract}

Keywords-SWOT analysis; general aviation; Shandong Province; strategy

\section{INTRODUCTION}

The term of general aviation was coined in the 1950s aboard. In 1986, the word "general aviation" replaced "professional aviation" by the State Council of China, which marked the connection to international general aviation industry of China. General aviation is an important part of civil aviation. According to the definition of China's civil aviation act in 1995, general aviation is refers to all the aviation activities using civil aircraft besides public air transport, which including all kinds of flying operation, such as industry, agriculture, forestry, fishery, construction, commerce, health, tourism, etc. General aviation has a large industrial group and long industrial chain, which involves in manufacturing, operation, maintenance, fuel, training, insurance and other business areas, consequently can promote economic development and has great economic value [1]. As a big economic Province, the general aviation industry has been developed rapidly in recent years and has gradually become an effective carrier to promote the economic development and improve people's livelihood in Shandong Province. SWOT analysis is an important organization development strategic analysis method, which is often used in business strategy formulation [2]. Using the SWOT analysis to analyze the development of general aviation industry in Shandong Province, study the strengths, weakness, opportunities and threats, can provide the basis for general aviation industrial policy and development strategy for Shandong Province [3].

\section{SWOT ANALYSIS OF GENERAL AVIATION INDUSTRY IN SHANDONG PROVINCE}

A. Strengths

1) Location and geographical strengths

As an important part of the bohai economic circle, Shandong Province also plays the role of a communication link between bohai sea economic zone and the Yangtze River Delta economic zone. At present, the Yellow River Delta efficient ecological economic zone and the Shandong Peninsula blue economic zone have risen to national strategy. In the international scope, Shandong Province is in the core regions of China, Japan and South Korea East Asia economic circle. According to the unique geographical strengths, we can make the domestic and international strategic layout, fully contact highway and high-speed railway, and then get complementary advantages and win-win results. At the same time, Shandong Province is rich in tourism resources, fairyland Penglai City, wonders of the Yellow River into the sea and so on, which are all the conditions to develop helicopter tourism projects.

\section{2) Economic strengths}

Shandong is one of China's big economic province and the second most populous province. In 2015, the GDP (gross domestic product) of Shandong Province has been reached 6.3 trillion yuan, is third in China, per capita income of $\$ 9575$. The development of general aviation industry is closely related to the economic base, when GDP per head reached $\$ 4000$, the general aviation industry will enter a rapid development channel [4]. At \$8000, the general aviation will be into explosive growth. At present, $1 / 10$ of China's top 500 enterprises and the top 500 private enterprises are in Shandong Province. Shandong also has the third of the country's aviation club number. Therefore, Shandong Province has the economic foundation to develop the general aviation industry.

\section{3) Policy strengths}

In July 2013, the State Council of China had issued "several opinions to promote the development of civil aviation", the development of civil aviation rose to national strategy. Civil aviation will be our new luminescent spot of next round of industrial upgrading. In 2011, the Shandong provincial government had introduced "the comments on accelerating the development of civil aviation" and "the twelfth five-year 
development plan of the aviation industry in Shandong Province". In October 2012, Shandong Provincial Government and the civil aviation administration signed "meeting notes for accelerating the development of civil aviation in Shandong". Then in the year 2014, General Office of Shandong Provincial Government had issued "plans for accelerating the development of civil aviation". This comment pointed out the construction of general aviation airport layout system, there would be 46 civil airports, including 16 aviation transportation airports. Shandong Province will actively develop all kinds of new type of general aviation services, such as emergency rescue, private flight, official flight, air lease and air sports etc. General aviation will become the new economic growth point of Shandong Province.

\section{4) Scientific research and education strengths}

Shandong Province is a big cultural province, which has very good higher education resources with 143 colleges and universities and many scientific research institutions. Especially in civil aviation talents cultivation, Binzhou University, Shandong Traffic Institute, Yantai Nanshan University, Linyi University and other colleges and universities have joined the cultivation of civil aviation talents. The aviation technologies and experiences of these colleges and universities have unique advantages to develop the general aviation industry. Shandong Province can rely on the intellectual resources of scientific research institutes and universities to promote the development of general aviation industry.

\section{5) Industry cluster strengths}

General Aviation Company in Shandong Province has developed rapidly in recent years. At present, there are fourteen general aviation companies in Shandong Province, accounting for $5.9 \%$ of the total general aviation companies of China, including ten 91 part companies, two 141 part companies and two 135 part companies, mainly in eight cities. Those companies have ninety-two general aviation aircrafts, accounting for $7.8 \%$ of the total general aviation aircrafts. The spatial agglomeration of those fourteen general aviation companies in Shandong Province can form competitive advantage of industrial clusters.

\section{B. Weakness Analysis}

1) Operations are greatly influenced by season and weather

The operation projects of general aviation in Shandong Province are mainly concentrated in flight training, air forest protection services and other service items [5]. Business aviation and flight entertainment projects accounted for a low proportion. Flight training and air forest protection services are greatly influenced by season and weather, aircraft utilization rate is not high and operational quantity is not enough, in general. The general aviation companies need to spend a lot of money in aircraft maintenance, payment of pilots and maintenance personnels, ect. The plight of the high cost and low returns is a great obstacle of the development of general aviation.

\section{2) Shortage of general aviation airport}

At present, Shandong Province has eight transport airports and four general aviation airports. The number of general aviation airports is insufficient and the distribution is relatively scattered [6]. However, general aviation needs more airports to meet the needs of take-off and landing. As a result, limited airports have affected the further development of general aviation in Shandong Province. If general aviation wants to form a mature industry chain, in addition to the aircraft, the necessary personnels and airspace capacity, a series of necessary supporting conditions are also needed. At present, the conditions to develop general aviation, such as aircraft maintenance, trusteeship, training, aviation emergency rescue, air navigation, air traffic control are insufficient; the corresponding supporting service facilities conditions are inadequate.

\section{3) Shortage of professionals}

Pilots and maintenance personnels are two kinds of professionals for general aviation which are also key factors restricting the development of general aviation [7]. Now, there are about one hundred pilots in Shandong Province, including seventy flight instructors. Meanwhile, Shandong Province has ninety-two general aviation aircrafts, calculating one aircraft needs two pilots, the quantities of pilots are not enough. Although there are many institutions for pilot training, such as Binzhou University, Yantai Nanshan University, Jiutian International Flight Academy, etc. But they mainly adopt "ordering" mode in civil air transport pilots training, and no cooperation with general aviation pilots training. The general aviation pilots training mode is usually at his own expense, average household can't afford it. Furthermore, compared with the civil aviation and military pilots, the income of general aviation pilots is lower, so there are a few pilots want to work in general aviation companies [8]. Licensed aviation maintenance personnels are only sixty in Shandong. Shortages of professionals seriously restrict the development of general aviation industry in Shandong Province.

\section{Opportunities Analysis}

1) Low altitude opens policy will support the development of general aviation industry

For many reasons, low-altitude in China has not been completely open, which became the main reason for restricting the development of general aviation. In 2008, the northeast and the Pearl River delta region started to reform low-altitude airspace management experimentation, the experimentation altitude was 1000 meters. In 2010, the State Council and the Central Military Commission of China introduced "Opinions about deepening the reform of China's low-altitude airspace management", which indicated the beginning of full development of low-altitude airspace and promotion of the general aviation development. In July 2012, the State Council introduced "several opinions to promote the development of civil aviation", which marked the development of civil aviation rose for national strategy. China introduced a series of policies, including simplifying approval procedures for general flight, relaxing private flight license standards and decentralizing airport construction approval authority etc. In November 2013, the Chinese People's Liberation Army General Staff and the Civil Aviation Administration of China (CAAC) jointly issued 
the "Approval and management regulations of general aviation flight mission". In December 2014, the State Council and National Air Traffic committee organized a national work conference on low-altitude airspace management reform, determined ten low altitude open cities, including Jinan and Qingdao in Shandong Province. Shandong Province attaches great importance to the development of general aviation, relying on the general aviation industry of Binzhou, Qingdao, Laiwu and Nanshan, has been built four general aviation industry sector, respectively are aircraft manufacturing in Binzhou, operation service in Qingdao, air sports in Laiwu and flight training in Nanshan. Shandong Province will cooperate with the CAAC in many ways, such as airport construction, opening an air route and general aviation services, etc. In addition, the Aviation Institute of Shandong, Shandong Aviation Industry Association, Association of Air Sports in Shandong and other civil organizations are also actively promoting the development of general aviation in Shandong Province.

\section{2) General aviation industry has broad prospects}

General aviation in China is a one trillion yuan industry with a huge market potential that not yet really started. In recent years, annual growth rate of China's general aviation industry is $10 \%$. According to the data provided by CAAC, in 2010, general aviation flight 139800 hours, an increase of $12.9 \%$ over the previous year. Among them: industrial aviation operation 63900 hours, an increase of 20.7\%. Agroforestry aviation operation 28200 hours, an increase of $7.2 \%$. Other operations 47700 hours, an increase of $6.9 \%$. Relevant experts predict that, in the next 10 years China will become the world's fastest-growing region in the business aviation market and need at least 1, 200 corporate aircrafts, various types of general aircraft numbers can reach one to two thousand. At present, China existing 875000 millionaires and 55000 billionaires. According to the survey, about $1 / 6$ of the rich plan to buy a private jet [9]. According to the aviation industry pull rate 1:10 estimation, by 2020, general aviation and its related industry in China will form the market size of at least 1 trillion yuan, and then the driving force of general aviation for employment is more apparent, with ratio of 1:12. The development of general aviation industry in Shandong Province will promote the region's economic and employment. With general aviation industry as the core, the industry can be formed a huge industrial chain, including aviation training, maintenance, consulting, financial leasing, insurance and so on, then promoting the development of other related industries.

\section{Threats Analysis}

\section{1) General aviation market is not stable}

General aviation market is the market with high investment, high return and high risk. General aviation is extensive, involved in various sectors of the national economy and with strong professional, so the general aviation market volatility is very big. As is known to all, due to the air operation characteristics, the general aviation operations are greatly influenced by factors such as weather and seasons, and disaster rescue and relief flight hours are closely related to disastrous situation [10]. Also, some projects will increase or decrease with the change of government policies. For general aviation operations, there are obvious peak season the off-season in one year, some aviation operating companies often purchase aircraft and other resources in order to meet the requirements of the peak season, but in the off-season, this can cause huge waste of resources and loss. Due to the market volatility of general aviation, general aviation enterprises generally face financial problems, which will cause an adverse effect on expansion of the enterprise and even lead to a vicious cycle. From the point of operation time in Shandong Province, flight training is occupied $83.9 \%$. The operation time distribution in mature aviation market is as following, flight training accounts for $20 \%$, flight entertainment accounts for $60 \%$ and public service flight accounts for $20 \%$. Thus, the industrial structures of general aviation in Shandong Province remains need further adjustment and the general aviation market remains need further development.

\section{2) Competition of domestic general aviation market is} intense

In July 2012, the State Council promulgated the development planning of the "twelfth five-year" national strategic emerging industry, and general aviation industry system was put forward. As strategic emerging industries, in addition to Shandong Province, general aviation caused the high attention of many local governments and had built aviation industrial park, including Liaoning, Tianjin, Shanghai, Shanxi, etc. How can Shandong Province compete successfully in numerous competition and attracting more general aviation industry in Shandong Province is crucial. Especially the economic development level of surrounding area of Shandong Province will produce strong competition to Shandong Province. Shandong Province is located in the Beijing-Tianjin urban agglomeration and Yangtze River delta urban agglomeration and will face greater competition in attracting investment.

\section{3) Risk of bottlenecks of excess capacity}

After the country determines to develop general aviation industry, the general aviation will usher in explosive growth. Local governments have raised a hot wave of the development of general aviation. Many aviation industrial parks have been constructed to promote investment and economic development. In consequence, bad phenomenon of blindly following and malicious hype will appear, lead to the same type layout, the hype, the low level competition and many other problems. In the development of general aviation industry chain, the imbalance between each link in the aviation industry supply chain, between upstream and downstream as well as the productive capacity and infrastructure will lead to the development of industry into a bottleneck of excess capacity.

\section{DeVelopment Strategy of General AViation INDUSTRY IN SHANDONG PROVINCE}

Based on SWOT analysis of the general aviation industry in Shandong Province, we put forward the following strategic advices about how to make full use of the strengths and opportunities, and then reduce the weaknesses and threats. As shown in figure 1. 


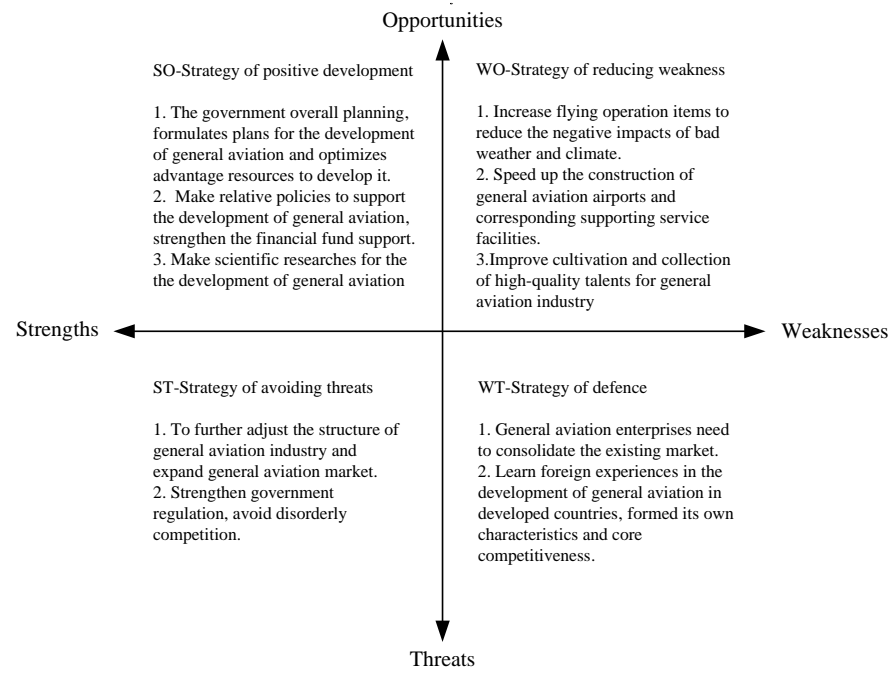

Fig. 1. SWOT strategic analyse matrix of general aviation industry development in Shandong Province

\section{CONCLUSION}

General aviation is an important part of civil aviation. The development level of general aviation is an important symbol of the development level of national science and technology, economic and people's living. Also is important in the social and economic development. In order to better development of general aviation, the government should overall planning, formulates plans for the development of general aviation and optimizes advantage resources to develop it. Make relative policies to support the development of general aviation, strengthen the financial fund support and speed up the construction of general aviation airports and corresponding supporting service facilities. Strengthen government regulation and avoid disorderly competition are also needed. For general aviation enterprises, they need to consolidate the existing market and increase flying operation items to reduce the negative impacts of bad weather and climate. More than that, the general aviation enterprises should form their own characteristics and core competitiveness.

\section{ACKNOWLEDGMENT}

This work was financially supported by the Soft science Research Project in Shandong Province (Grant No. 2015RKB01102).

\section{REFERENCES}

[1] S.E. Jackson, A. Joshi and N.L. Erhardt, "Recent Research on Team and Organizational Diversity: SWOT Analysis and Implications," Journal of Management, vol. 29, pp. 801-830, 2003.

[2] F. Fliegen, General Aviation Kalender, Elementbuch, 2014.

[3] H. Yuan, "A SWOT analysis of successful construction waste management,” Journal of Cleaner Production, vol. 39, pp. 1-8, May, 2013.

[4] J. Marana, "HOW A GENERAL AVIATION AIRPORT CAN BENEFIT YOUR BUSINESS,” Business People, vol. 27, pp. 26, June, 2014.

[5] T. Hill, "Westbrook R. SWOT analysis: It's time for a product recall," Long Range Planning, vol. 30, pp. 46-52, Jaunary, 1997.

[6] R.G. Dyson, "Strategic development and SWOT analysis at the University of Warwick," European Journal of Operational Research, vol. 152, pp. 631-640, March, 2004.

[7] R.C.D. Paiva, M.T. Dur and H. Faisal, "Spatiotemporal interpolation of discharge across a river network by using synthetic SWOT satellite data," Water Resources Research, vol. 51, pp. 430-449, Jaunary, 2015.

[8] G. Wall, "A SWOT Analysis of Tourism in Baoting, Hainan, China," International Journal of Tourism Sciences, vol. 2, pp. 37-48, Jaunary, 2015.

[9] M. Thurber, "Resource sharing comes to small general aviation aircraft," Allevatore Di Ovini E Caprini, vol. 147, pp. 519-536, May, 2014.

[10] H. Zhai, Y. Hao and X. Guan, "State-of-the-arts and prospects of manufacturing and application of titanium alloy tube in aviation industry,” Journal of Plasticity Engineering, vol. 16, pp. 44-46, April, 2009 